\title{
Genel Sinizm ve Örgütsel Sinizm İlişkisi Üzerine Bir Araştırma
}

\section{A research on the relationship between general cynicism and organizational cynicism}

\section{Emine ÖNDEŞ ${ }^{1 a}$ \\ Ayşe İRMiş ${ }^{2}$}

\author{
1 Pamukkale Üniversitesi, Sosyal Bilimler Enstitüsü, Denizli. emineondes@gmail.com \\ 2 Pamukkale Üniversitesi, İktisadi ve İdari Bilimler Fakültesi, Denizli. airmis@pau.edu.tr \\ a Yazışlan yazar/Corresponding author
}

\begin{abstract}
Özet
Araştırmanın amacı bireylerin genel sinizm ve örgütsel sinizm düzeylerini saptamak ve genel sinizm ile örgütsel sinizm arasındaki ilişkiyi irdelemektir. Araştırmada 5'li Likert Ölçeği kullanılmış ve anketler Denizli'de yer alan tekstil firmalarında uygulanmıştır. Araştırmanın örneklemini oluşturabilmek için 210 adet anket dağıtılmış ancak 156 adet anket üzerinde analiz yapulabilmiştir. Genel sinizm eğilimini ölçmek amactyla Wrightsman'm 1992'de geliştirdi ̌̆i, Erdost ve diğerlerinin uyarladı̆̆ on sorudan oluşan genel sinizm ölçeği, örgütsel sinizm eğilimini ölçmek amacryla ise Brandes'in 1997'de geliştirdiği Kalağan (2009)'ın uyarladı̆̆ı bilişsel, duyuşsal ve davranışsal olarak üç boyuttan oluşan on üç sorunun yer aldığı örgütsel sinizm ölçeği kullanılmıştır. Elde edilen veriler istatistiksel analize tabi tutularak yorumlanmıştır. Araştırma bulguları sonucunda genel sinizm ve örgütsel sinizm arasında düşük ama anlamlı bir ilişki bulunmuştur. Genel sinizm ve örgütsel sinizmin boyutları arasındaki ilişki incelendiğinde ise genel sinizmin etkisi en çok örgütsel sinizmin bilişsel boyutu üzerinde görülmektedir. Genel sinizmin davranışsal boyut üzerindeki etkisinin orta düzeyde ve anlaml, duyuşsal boyut üzerindeki etkisinin ise düşük seviyede ve anlamlı olduğu görülmektedir.
\end{abstract}

Anahtar kelimeler: Sinizm, Örgütsel sinizm

JEL kodlari: M10, M12, M14.

\begin{abstract}
The aim of this study is to determine the general levels of cynicism and organizational cynicism of individuals and the extent to which individuals who are inclined to general cynicism reflect this to their organization. Likert Scale was used and The surveys were applied to textile companies located in Denizli. In order to establish the sample of the study, 210 questionnaires were distributed but the sample was prepared with 156 questionnaires. The general cynicism scale, which was developed by Wrightsman in 1992 and composed of ten questions adapted by Erdost and others, was used to measure general cynicism tendency and in order to measure the tendency of organizational cynicism, the organizational cynicism scale, which was developed by Brandes in 1997 and which was adapted by Kală̆an (2009) in three dimensions of cognitive, affective and behavioral dimensions, was used. The obtained data were interpreted by applying necessary statistical analysis. As a result of research findings, a low but significant relationship was found between general cynicism and organizational cynicism. When the relationship between the general cynicism and the dimensions of organizational cynicism is examined, the effect of general cynicism is mostly seen on the cognitive dimension of organizational cynicism. The effect of general cynicism on the behavioral dimension is moderate and meaningful and the effect on the affective dimension is low and significant.
\end{abstract}

Keywords: Cynicism, Organizational cynicism

JEL codes: M10, M12, M14. 


\section{GİRiş}

Sinizm kavramı Antik Yunan'da, bir düşünce tarzı ve yaşam biçimi olarak ortaya çıkmıştır (Brandes, 1997: 7). İlk sinik Sokrates' in öğrencisi Antisthenes olarak bilinmektedir (Mantere ve Martinsuo, 2001:4). Aynı zamanda Antisthenes Atina'da kurulan sinik (kinik) okulunun kurucusudur (Weber, 1998: 47). Sinik felsefesinin diğer bir önemli temsilcisi de Diogenes'tir. En eski siniklerden kabul edilen Antisthenes ve Diogenes en büyük mutluluğun erdemli olma ve bireylerin kendi kendilerine yetebilmelerinde olduğunu savunmuşlardır (Özgener, 2008: 53).

Özellikle karşılıklı güvenin söz konusu olmadığı toplumlarda yer alan bireylerde sinizm yaygın olarak görülen bir kişilik özelliğidir. Sinizm eğiliminde olan bireyler, diğer insanlara kolay kolay güvenmez, insanların samimiyet ve dürüstlükten yoksun olduklarını düşünür, onları yalancı, bencil, samimiyetsiz ve sahte insanlar olarak nitelendirirler. Sinik insanlar karşısındaki insanları bencil olarak gördükleri için onlara yardımsever ve arkadaşça davranmazlar. İnsanların davranışlarının arkasında başka niyetler yattığını düşünürler dolayısıyla tutarsız davranışlar sergilediklerine ve güvenilir olmadıklarına inanırlar.

Sinizm eğilimi bireyin kendi kişilik özellikleri ve hayata bakış açısından kaynaklanıyorsa 'genel sinizm', örgütsel faktörleri esas alan durumlardan kaynaklanıyorsa 'örgütsel sinizm' olarak adlandırılır (Erdost vd., 2007: 515). Genel sinizmin hâkim olduğu bireylerde küçük görme, öfke, utanç ve sıkıntı gibi duygusal unsurlar güçlü negatif duyguları harekete geçirmektedir. Dünyanın sosyal ilişkilerden memnun olmayan, bencil, kayıtsız ve ilgisiz, yalancı insanlarla dolu olduğunu düşünürler ve eylemlerini bu yargıya göre oluştururlar. Bu inanca göre bireyler gerçekte ne olduğuyla ilgilenmez ve çıkarları doğrultusunda hareket ederler (Abraham, 2000: 269). Örgütlerde ise sinik bireyler örgüteki uygulamaların adil ve güvenilir olmadığını ve diğer çalışanların eylemlerini ahlâk ilkeleri adına değil kendi çıkarlarını gerçekleştirmek uğruna yaptıklarını düşünürler. Bu sebeple sinik bireyler negatif tutum ve davranışlarını örgütlerine yansıtırlar. Aynı zamanda örgütte karşılaşılan dürüst ve adil olmayan uygulamaların deneyimlenmesi de örgütsel sinizmin sebebini oluşturmaktadır.

\section{2. ÖRGÜTSEL SINIIZM}

Örgütsel sinizm kavramının temelini dürüstlük, adalet, samimiyet ve içtenlik ilkelerinden yoksunluk oluşturmaktadır. Böyle bir yoksunluk dürüstlük, adalet ve samimiyet ilkelerinin, kişisel liderlik çıkarlarını arttırmak için feda edildiği ve aldatmaya dayalı eylemlere yol açtığı inancını ortaya çıarmaktadır (Abraham, 2000: 269). Bireyde örgütün dürüstlükten yoksun olduğuna dair kuvvetli bir inanç vardır ve bu inanç güçlü negatif duygularla birleştiğinde bireyin kritik davranışlar göstermesine neden olmaktadır. Bu sebeple örgütsel sinizm, iş tatminsizliği ve örgüte yabancılaşma, örgütün kendisine, vaatlerine ve çalışanlarına karşı soğuma ve örgüte güvensizlik içinde olmayla doğrudan ilişkili bir kavramdır. Bireyler örgütün dürüstlükten yoksun olduğuna ve kendilerine ihanet ettiğine inandıkları için örgüte karşı öfke, kınama, utanç ve tiksinti gibi duygular beslerler. Bu beslenen duygular bireyde eleştiri ve alay gibi davranışsal boyutlara dönüşerek örgütüne karşı sinizm beslemesine yol açar.

Örgütsel sinizm kişinin örgütüne karşı takındığı olumsuz tutumdur ve örgütün bütünlükten yoksun olduğuna dair inanç, örgüt ile olumsuz etkileşim ve örgütü küçümseme eğilimleri 
şeklinde kendini gösterir. Bu inanç ve eğilimler bireyin örgütüne karşı davranışlarının nasıl olacağını belirler. Örgütsel sinizmi oluşturan boyutlar bilişsel, duyuşsal ve davranışsal boyuttur (Ajzen, 2001: 27-28). Bilişsel boyut, örgütün bütünlükten yoksun olduğu inanciyla ortaya çıkmaktadır. Bireyler örgütlerinin dürüstlük, adalet ve samimiyet ilkelerine ihanet ettiğine ve örgütlerinde bu ilkelerin yöneticilerin menfaatleri uğruna feda edildiğine inanmaktadırlar. Sinik bireyler çoğunlukla yöneticilerin eylemlerinin ardında gizli niyetlerin olduğunu düşündükleri için yöneticilerden açı sözlülük yerine aldatmaca ve hileli davranış görmeyi beklerler ve örgütsel kararlar alınırken örgütün ana değerlerinin dikkate alındığına inanmazlar (Dean ve diğ, 1998: 345-346). Örgütün dürüstlüğüne dair inancın olmamas1 kişilerde öfke, hor görme, kınama, hayal kırıklığı gibi olumsuz duyguları ortaya çıkarır. Sinizmin ikinci boyutu duyuşsal boyuttur. Duyuşsal boyuta göre sinizm, inanç ve düşüncelerin yanı sıra sosyal hayatta yaşanılan duygusal etkileşimlerle oluşan deneyimler sonucunda hissedilir ve örgüt hakkında oluşan tarafsız yargılardan ziyade güçlü duygusal tepkileri içerir. Izard (1977) yapmış olduğu çalışmada siniksel tutumların duygusal bileşenlerini kavramsallaştırmıştır. Bu bileşenler her biri hafif ve güçlü bir biçimde tanımlanan ilgi-heyecan / haz-neşe / şaşkınlık-ürkmek / üzüntü-ızdırap / öfke-hiddet / bıkkınlık- iğrenme / küçümseme-hor görme / endişe-dehşet / utanç-küçük düşürme şeklindeki dokuz temel duygudan oluşmaktadır (Demir, Ayas, Yıldız, 2018:234). Örgütsel sinizmin duyuşsal boyutu bu duyguların birçoğunun hissedilmesiyle meydana gelmektedir. Örgütsel sinizmin son boyutu olan davranışsal boyut olumsuza doğru yüz tutmuş ve çoğunlukla üstlerine karşı küçümseme içeren davranışlar ile ifade edilir. Genel algıya göre sinik tutumlar, özel davranış kalıplarından ziyade, davranış türlerine yönelik eğilimleri içerir (Ajzen, 1994: 27-58). Sinik davranışlar çeşitli şekillerde karşımıza çıkabilir ancak en doğrudan olanı, örgütün dürüstlük, samimiyet ve buna benzer ahlaki değerlerden yoksun olduğu yönündeki açık sözlü ifadelerdir. İşgörenler alaycı tutumlarını belli etmek amacıyla özellikle kinayeli mizahı kullanabilirler. Örgütte, örgütsel bütünlügüun eksik olduğu varsayılan olayların meydana gelmesi ve alaycı bir şekilde yorumlanması örgütsel sinizmi karakterize eden bir davranış eğilimi olarak karşımıza çıkmaktadır.

\section{1. Örgütsel Sinizm Türleri}

Örgütsel sinizm; kişilik, toplumsal, işgören, örgütsel değişim ve meslek sinizmi olmak üzere beşe ayrılmaktadır. Kişilik sinizmi doğuştan gelen, dengeli ve istikrarlı bir kişilik özelliğini yansıtan, genellikle olumsuz tutum ve davranışlardır. Kişilik sinizmi yaşayan bireylerde dünyanın dürüst olmayan, kötülüklere göz yuman, ilgisiz, ihmalkâr ve bencil insanlarla dolu olduğu genellemesi oluşmuştur. Bireyde diğer insanlara karşı kökleşmiş güvensizlik ve yerleşmiş şüphe duygusu hâkimdir. Bu yüzden de diğerlerinin samimiyetine de iyiliğine de inanmazlar, aksine onları sahte bulurlar ve onlara kaba davranışta bulunma eğilimi gösterirler (Abraham, 2000: 270-271). Toplumsal sinizm, birey ve toplum arasındaki toplumsal sözleşme ve sosyal anlaşma kurallarına uyulmadığı düşüncesi oluştuğunda ortaya çıkan tavır ve tutumlardır. Birey ve toplum arasındaki karşılıklı psikolojik sözleşme ihlalinin bireylerin güvenini kırdığı söylenebilir ve bu güven kırıklığı neticesinde bireyde kişisel olarak haksızlığa uğramış hissi, düzene duyulan güvenin sarsılması ve sistemin bozulduğuna dair inanç baş gösterir. İşgören sinizminin etkin olduğu yerler tepe yönetimleri, çalışma alanındaki tüzel varlıklar ve büyük faaliyet alanlarıdır (Anderson ve Bateman, 1997: 449-452). Örgüt yöneticileri resmi kuralları ihlal etmek, resmi anlaşmaları çiğnemek gibi adil olmayan 
prosedürler uyguladıklarında ve yönetici olmanın beraberinde getirdiği sorumlulukları layıkıyla yerine getiremediklerinde astların güvenini ve kendilerine duyulan saygınlığı kaybederler (Bies ve Tripp, 1996: 246-260). Örgütlerdeki başarısız değişim girişimlerinde, sarf edilen çabaların gelecekte başarı sağlayamayacağına dair oluşan olumsuz inançtan dolayı ve rekabet etmede tembel tutumlar sonucunda örgütsel değişim sinizmi kendini göstermeye başlar. Örgütte uygulanmaya çalışılan değişim çabalarının başarısızlığı sıklaştığında ve birbirini izlediğinde çalışanlarda hayal kırıklığı ve kendini ihanete uğramış hissi meydana gelir; bu hislerin oluşturduğu kötümser tutum nedeniyle kendilerinde örgüte karşı bir savunma mekanizması oluştururlar. Stresli iş ortamının hâkim olduğu örgütlerde işgörenler kendilerini duygusal olarak yıpranmış ve fiziksel olarak da tükenmiş, bitkin hissederler. Meslek sinizmi yaşayan bireyler genellikle profesyonel yardım almayan, problem çözme odaklı olmayan, başarısız, olumsuz ve şişirilmiş geri dönüşler alan, sabırsız ve çoğunlukla iş birliği içinde olmayan özelliktedirler. Birey kendi değer yargıları ile örgütün değer yargılarının uymadığını düşündüğü zaman mesleki sinizmin oluşmasına sebebiyet verir ve müşterileri veya iş arkadaşları ile stresli bir etkileşim içinde olması da bu durumu pekiştirir. Meslek sinizmi yaşayan insanlar mesleklerine karşı duygusuz, umarsız, vurdumduymaz ve baştan savan bir tavır takınırlar (Abraham, 2000: 272-273).

\subsection{Literatür Araştırması}

Örgütsel sinizm yeni bir konu olarak karşımıza çıkmaktadır ve gelişim aşaması devam etmektedir. Brandes ve arkadaşları (1999) fabrika çalışanlarından 129 yönetici ve işgörenin katıldığı bir çalışma yapmışlardır. Araştırmanın bileşenlerini örgütsel sinizm ile örgütsel bağl1lık, örgütsel vatandaşlık, çalışan ve yöneticinin katılımı, yöneticinin biçimsel ve ekstra rol davranışı oluşturmaktadır. Araştırma sonuçlarına göre örgütsel sinizm ile örgütsel bağlılık arasında güçlü ve negatif, örgütsel sinizm ve çalışan katılımı arasında orta düzeyde negatif ve örgütsel sinizm ve yöneticilerin biçimsel rol davranışı arasında da düşük düzeyde negatif bir ilişki olduğu saptanmıştır. Sinizm gösteren çalışanların yöneticilere kıyasla örgütsel bağlılık ve çalışan katılımlarının daha az olduğu ortaya konmuştur.

James (2005) Amerika'nın güneydoğusunda 17 okul bölgesinde görev yapmakta olan 360 çalışan ile örgütsel sinizmi oluşturan temel faktörler, örgütsel sinizmin ara değişkenleri ve örgütsel sinizmin sonuçlarını belirlemeyi amaçlayan bir çalışma gerçekleştirmiştir. Araştırma sonucunda, örgütsel sinizmi oluşturan temel faktörleri psikolojik sözleşme, örgütsel adalet, örgütsel politika ve algılanan örgütsel destek, ara değişkenleri örgütsel ruh ve kontrol odağ1 ve örgütsel sinizmin sonuçlarını da çalışan uyumsuzluğu, iş gerilimi, örgütsel vatandaşlık, performans ve zarar veren iş davranışları olarak belirlemiştir.

Tokgöz ve Yılmaz (2008) tarafından, Eskişehir il merkezinden 8, Alanya'dan 9 olmak üzere toplam 17 otel işletmesindeki 346 çalışanın genel sinizm ve örgütsel sinizm seviyeleri ve demografik değişkenleri arasındaki ilişkilerin analiz edildiği bir çalışma yapılmıştır. Bu çalışmanın bulgularına göre genel sinizm ile örgütsel sinizm arasında kısmen bir ilişki vardır ve eğitim düzeyi yükseldikçe sinizm seviyesi artmaktadır. Ayrıca, kıyı otel işletmelerinde çalışanlar şehir otel işletmelerinde çalışanlara göre daha siniktir ve mevsimlik çalışanlar kadrolu çalışanlara göre daha yüksek seviyelerde sinizm belirtileri göstermektedir. Çalışmada genel sinizm ve örgütsel sinizm arasında düşük ama anlamlı bir ilişki bulunmuştur. Genel 
sinizmin örgütsel sinizmin bir kaynağı olduğu ve genel sinizm seviyesi arttıkça örgütsel sinizm seviyesinin de arttı̆̆ görülmüştür.

Kalağan ve Güzeller 2007-2008 eğitim-öğretim yılında Antalya il merkezinde ilköğretim ve ortaöğretim kurumlarında görev yapan 325 öğretmenin katıldığ gerçekleştirmiştir. Araştırmanın amacı öğretmenlerin örgütsel sinizm düzeylerinin saptanmasıdır. Araştırmanın bulguları incelendiğinde ise öğretmenlerin cinsiyetleri, medeni durumları ve yaşları ile örgütsel sinizm düzeyleri arasında anlamlı bir ilişki saptanmamıştır. Ancak örgütsel sinizm ile öğretmenlerin mesleki kıdemleri arasında anlamlı bir ilişki kurulmuş, genellikle öğretmenlerin mesleki kıdemleri azaldıkça örgütsel sinizm düzeylerinin arttığ1 gözlenmiştir.

Arslan (2012)' in Süleyman Demirel Üniversitesi İktisadi ve İdari Bilimler Fakültesinde görev yapan 80 akademisyen üzerinden yürüttüğü araştırmasında akademik personelin genel ve örgütsel sinizm düzeylerini belirlemek amacıyla iki ölçek uygulamıştır. Araştırma sonucunda akademisyenlerin genel ve örgütsel sinizm düzeyleri orta seviyede gözlenmiş ve örgütsel sinizm ile genel sinizm eğilimleri arasında pozitif yönde ve düşük düzeyde ilişkiler olduğu ortaya konmuştur.

Akman (2013), “Sağlık Çalışanlarının Örgütsel ve Genel Sinizm Düzeylerinin Karşılaştırılması" adı altında personellerin genel ve örgütsel sinizm düzeyleri ve demografik özelliklerin genel ve örgütsel sinizm ile olan ilişkisini ortaya koymayı amaçlayarak İstanbul ilinde özel hastanede görev yapan 168 çalışan ile bir çalışma yapmıştır. Çalışma sonucunda demografik özellikler ile örgütsel sinizm ve genel sinizm arasında anlamlı farklılıklar bulunmuştur ve genel sinizm işinden memnun olma düzeyine ve çalışılan bölüme göre farklılık göstermiştir. Yaş ve medeni durum değişkenleri incelendiğinde ise genel olarak bir ilişki saptanmamıştır.

\section{GENEL SINIZZM VE ÖRGÜTSEL SINIZM ARASINDAKI İLIŞKINIIN İNCELENMESINE YÖNELIKK BİR ARAŞTIRMA}

\subsection{Araştırmanın Amacı}

Yapılan araştırmada iki amaç yer almaktadır. Birincisi, katılımcıların genel sinizm ve örgütsel sinizm düzeylerini ölçmektir. Araştırmanın ikinci amacı ise genel sinizm ile örgütsel sinizm arasındaki ilişkiyi test etmektir. Bu amaç doğrultusunda geliştirilen hipotez;

H1: Genel ve Örgütsel sinizm arasında anlamlı bir ilişki vardır.

\subsection{Yöntem}

Çalışmada, veri toplama aracı olarak anket tekniği seçilmiştir. Anket formu araştırmanın amacını, çalışmanın içeriğini ve yararlanılan bilgilerin gizliliğini ifade eden bir bölümle başlamaktadır ve üç bölümden oluşmaktadır. İlk bölümde katılımcıların demografik özelliklerini belirlemek amacıyla kişisel bilgilerden oluşan sekiz soru yer almaktadır. İkinci bölümde Wrightsman'ın 1992' de geliştirdiği, Erdost ve diğerlerinin uyarladığı on sorudan oluşan genel sinizm ölçeği, üçüncü bölümde ise Brandes'in 1997'de geliştirdiği Kalağan (2009)' in uyarladığı bilişsel, duyuşsal ve davranışsal olarak üç boyuttan oluşan on üç sorunun yer aldığı örgütsel sinizm ölçeği kullanılmıştır. Araştırmada kullanılan anket farklı birçok bilimsel araştırmada kullanılmış ve o araştırmalarda güvenilir sonuçlar alınmıştır, bu sebeple 
ön test yapmaya gerek duyulmamıştır. Katılım düzeylerini ölçmek amacıyla 5'li Likert ölçeği kullanılmıştır. Ölçekteki sıklık dereceleri “1. Kesinlikle Katılmıyorum”, “2. Katılmıyorum”, “3. Kararsızım”, “4. Katılıyorum”, “5. Kesinlikle Katılıyorum” şeklindedir.

\subsection{Evren ve Örneklem}

Araştırmanın evrenini İstanbul Sanayi Odası'nın belirlediği Türkiye'nin 500 Büyük Sanayi Kuruluşu ve Türkiye'nin İkinci 500 Büyük Sanayi Kuruluşu listesinde yer alan Denizli'deki tekstil firmaları oluşturmaktadır. Araştırma evreninin kapsamına yedi tekstil firması girmektedir. Araştırma örneklemini oluşturabilmek için firmalara anketler bırakılmış ve daha sonra belirlenen zamanlarda toplanmıştır. Toplamda 210 adet anket dağıtılmış ancak 163 tanesi geri alınabilmiştir. Geri alınan anketlerden de 7'si eksik ve hatalı cevaplama nedeniyle değerlendirmeye alınmamıştır. Sonuç olarak 156 anket ile araştırmanın analizleri yapılmıştır.

\subsection{Bulgular}

Araştırmanın verileri SPSS 15.0 istatistik paket programında analize uygun hale getirilmiştir. Uygulanan analizlerde demografik özellikler ve genel ve örgütsel sinizm düzeylerinin belirlenmesi amacıyla betimleyici istatistikler hesaplanmıştır.

\subsubsection{Katılımcıların Demografik Özellikleri}

Katılımcıların demografik özellikleri ile ilgili bilgiler Tablo 1'de gösterilmektedir. Tablo incelendiğinde, araştırmaya katılanların \%55,1'inin (86) kadın, \%44,9'unun (70) ise erkek olduğu görülmektedir. Medeni durumlarına bakıldığında ise \%37,2'si (58) bekâr, \%62,8'i (98) evlidir.

Çalışanların \%60,2'si 18-35 yaş grubunda, \%39,8'i 35 yaş üstü gruptadır. Oranlara baktığımızda ise araştırmaya katılan çalışanların çoğunluğunun orta yaş üstü ve orta yaş olduğu görülmektedir. Eğitim düzeylerine bakıldığında ise en yüksek paya lise $(\% 35,9)$ ve lisans $(\% 33,3)$ mezunlarının sahip olduğu görülmektedir.

Katılımcıların \%34'ü en fazla 5 yıla kadar, \%29,5'i 6-11 yıl, \%36,5'i 15 yıl ve daha fazla süredir mesleklerinde görev yapmaktadır. Şu an çalışmakta oldukları yerdeki görev sürelerine bakıldığında ise \%78,8'i 1-14 yıldır, \%21,2'si 15 yıl ve daha fazla süredir görev yapmaktadır. Görevlerine bakıldığında ise araştırmaya katılanların sayısının yarıdan fazlasını $(\% 57,1)$ yönetimde söz sahibi olmayanların oluşturduğu görülmektedir. Katılımcıların \%23,7' si Yetkili / Yetkili Yrd. / Uzman Yrd. , \%10,9'u Memur / Stajyer Memur, \%4,5'i Müdür Yrd. / Üst Yetkili / Uzman, \%3,2'si Müdür ve \%0,6'sı Başkan /Bölge Müdürü'dür.

Çalışanların gelir düzeyleri incelendiğinde ise katılımcıların \%25,6'sı 1500 altında, \%65,4'ü 1500-3000 arası ve \%' ’u 3001 ve üzeri maaş almaktadır. Gelir dağılımına baktığımızda çalışanların önemli kısmının (\%91,0) 3000' den daha düşük miktarda maaş aldığı söylenebilir. 
Tablo 1. Katılımcılara ilişkin demografik bilgiler

\begin{tabular}{|c|c|c|c|}
\hline Demografik Özellikler & Sinif & Sayı & Yüzde \\
\hline \multirow{2}{*}{ Cinsiyet } & Kadın & 86 & 55,1 \\
\hline & Erkek & 70 & 44,9 \\
\hline \multirow{5}{*}{ Yaş } & 18-25 Yaş Arası & 18 & 11,5 \\
\hline & 26-35 Yaş Arası & 76 & 48,7 \\
\hline & 36-45 Yaş Arası & 52 & 33,4 \\
\hline & 46-55 Yaş Arası & 8 & 5,1 \\
\hline & 55 Yaş Üstü & 2 & 1,3 \\
\hline \multirow{2}{*}{ Medeni Durum } & Bekâr & 58 & 37,2 \\
\hline & Evli & 98 & 62,8 \\
\hline \multirow{6}{*}{ Eğitim Düzeyi } & İlköğretim & 19 & 12,2 \\
\hline & Lise & 56 & 35,9 \\
\hline & Ön Lisans & 14 & 9,0 \\
\hline & Lisans & 52 & 33,3 \\
\hline & Yüksek Lisans & 15 & 9,6 \\
\hline & Doktora & - & - \\
\hline \multirow{5}{*}{ İş Hayatı Tecrübesi } & 1 Ylldan Az & 12 & 7,7 \\
\hline & 1-5 Y1l Aras1 & 41 & 26,3 \\
\hline & 6-10 Y11 Arası & 32 & 20,5 \\
\hline & 11-14 Y1l Aras1 & 14 & 9,0 \\
\hline & 15 Yıl ve Üzeri & 57 & 36,5 \\
\hline \multirow{5}{*}{ İşletmede Çalışma Süresi } & 1 Yıldan Az & 30 & 19,2 \\
\hline & 1-5 Yil Arası & 50 & 32,1 \\
\hline & 6-10 Y1l Arası & 27 & 17,3 \\
\hline & 11-14 Y1l Aras1 & 16 & 10,2 \\
\hline & 15 Yll ve Üzeri & 33 & 21,2 \\
\hline \multirow{6}{*}{ Görev } & Diğer & 89 & 57,1 \\
\hline & Memur/Stajyer Memur & 17 & 10,9 \\
\hline & Yetkili / Yetkili Yrd. / Uzman Yrd. & 37 & 23,7 \\
\hline & Müdür Yrd. / Üst Yetkili / Uzman & 7 & 4,5 \\
\hline & Müdür & 5 & 3,2 \\
\hline & Başkan / Bölge Müdürü & 1 & 0,6 \\
\hline \multirow{5}{*}{ Gelir Düzeyi } & 1500 Altı & 40 & 25,6 \\
\hline & 1500-3000 Aras1 & 102 & 65,4 \\
\hline & 3001-4500 Aras1 & 6 & 3,8 \\
\hline & 4501-6000 Arası & 2 & 1,4 \\
\hline & 6001 ve üzeri & 6 & 3,8 \\
\hline
\end{tabular}

\subsubsection{Katılımcıların Genel Sinizm Düzeyleri}

Genel sinizm eğilimini ölçmek üzere ölçeğe uygulanan güvenilirlik analizi sonucunda Cronbach's Alpha değeri 0,734 olarak hesaplanmıştır ve bu değer ölçeğin güvenilir olduğunu göstermektedir. Genel sinizm ölçeğinde yer alan maddeler ve bu maddeler ilişkin ortalama ve standart sapmalar Tablo 2' de yer almaktadır. 
Tablo 2. Genel Sinizm Eğilimine Yönelik Ortalama ve Standart Sapmalar

\begin{tabular}{|c|c|c|c|}
\hline Ölçek Maddeleri & $\mathbf{N}$ & $X$ & ss \\
\hline $\begin{array}{l}\text { İnsanlar görülmeyeceklerinden emin olsalar bir sinemaya ücretini ödemeden } \\
\text { girerlerdi. }\end{array}$ & 156 & 3,49 & 1,257 \\
\hline Siradan olan insan kibirlidir. & 156 & 2,44 & 1,114 \\
\hline $\begin{array}{l}\text { Ahlaki değerlere sahip olan bir öğrenci bile bir sınavda herkes kopya çekiyorsa } \\
\text { kopya çekecektir. }\end{array}$ & 156 & 2,75 & 1,178 \\
\hline Çoğu insan çıkar elde edeceğini düşündüğünde yalan söyleyebilir. & 156 & 3,58 & ,997 \\
\hline $\begin{array}{l}\text { Maalesef ki günümüzde kendi çıkarlarını düşünmeyen insan çoğu insan tarafından } \\
\text { kandırılır. }\end{array}$ & 156 & 3,79 & 1,078 \\
\hline $\begin{array}{l}\text { İnsanlar dürüst ve ahlâklı olduklarını iddia ederler ama para kaybedeceklerse çok az } \\
\text { insan bu değerlere sadik kalır. }\end{array}$ & 156 & 3,74 & ,984 \\
\hline $\begin{array}{l}\text { İnsanlar birbirlerine gerçek değerlerinden daha fazla önem veriyormuş gibi } \\
\text { görünürler. }\end{array}$ & 156 & 3,64 & ,936 \\
\hline İnsanlar başkalarına yardım etme zahmetine girmekten hoşlanmazlar. & 156 & 2,97 & 1,133 \\
\hline Çoğu insan eğer fırsatını bulursa vergi kaçırır. & 156 & 3,65 & 1,014 \\
\hline $\begin{array}{l}\text { Çoğu insan olması gerektiğine inandığı için değil yakalanmaktan korktuğu için } \\
\text { dürüsttür. }\end{array}$ & 156 & 2,91 & 1,149 \\
\hline Tüm ölçek & & 3,3 & 1,09 \\
\hline
\end{tabular}

Tablo incelendiğinde, araştırmaya katılan çalışanların "İnsanlar görülmeyeceklerinden emin olsalar bir sinemaya ücretini ödemeden girerlerdi" maddesine $(3,49)$ katılıyorum, "Siradan olan insan kibirlidir" maddesine $(2,44)$ katılmıyorum, "Ahlaki değerlere sahip olan bir öğrenci bile bir sınavda herkes kopya çekiyorsa kopya çekecektir" maddesine $(2,75)$ kararsızım, "Çoğu insan çıkar elde edeceğini düşündüğünde yalan söyleyebilir" maddesine $(3,58)$ katıllyorum, "Maalesef ki günümüzde kendi çıkarlarını düşünmeyen insan çoğu insan tarafından kandırılır" maddesine $(3,79)$ katılıyorum, "İnsanlar dürüst ve ahlâklı olduklarını iddia ederler ama para kaybedeceklerse çok az insan bu değerlere sadik kalır" maddesine $(3,74)$ katılıyorum, "İnsanlar birbirlerine gerçek değerlerinden daha fazla önem veriyormuş gibi görünürler" maddesine $(3,64)$ katılıyorum, "İnsanlar başkalarına yardım etme zahmetine girmekten hoşlanmazlar" maddesine $(2,97)$ kararsızım, "Çoğu insan eğer firsatını bulursa vergi kaçırır" maddesine $(3,65)$ katılıyorum, "Çoğu insan olması gerektiğine inandı̆̆ 1 için değil yakalanmaktan korktuğu için dürüsttür" maddesine $(2,91)$ kararsızım cevabını verdiği görülmektedir. Ölçek ortalaması ise $(3,3)$ kararsızım olarak ifade edilmiştir. Değerler incelendiğinde her ne kadar cevapların kararsızım etrafında toplandığı görülse de böyle bir durumun orta düzey bir sinizme işaret ettiği söylenebilir. Özellikle bazı maddelerde ortalamaların katılıyorum ifadesine yakın olduğunu göstermesi orta düzey sinizmin varlığını kuvvetlendirmektedir. Bu nedenle çalışanların genel sinizm düzeylerinin orta seviyede olduğu söylenebilir.

\subsubsection{Katılımcıların Örgütsel Sinizm Düzeyi}

Örgütsel sinizm eğilimini ölçmek üzere ölçeğe uygulanan güvenilirlik analizi sonucunda Cronbach's Alpha değeri 0,889 olarak hesaplanmıştır ve bu değer ölçeğin güvenilir olduğunu göstermektedir. Örgütsel sinizm ölçeğinde yer alan maddeler ve bu maddelere ilişkin ortalama ve standart sapmalar Tablo 3 'te yer almaktadır. 
Tablo 3. Örgütsel Sinizm Eğilimine Yönelik Ortalama ve Standart Sapmalar

\begin{tabular}{|c|c|c|c|}
\hline Ölçek Maddeleri & $\mathbf{N}$ & $\mathbf{X}$ & ss \\
\hline Çalıştığım kurumda söylenenler ile yapılanların farklı olduğuna inanıyorum & 156 & 3,31 & 1,189 \\
\hline $\begin{array}{l}\text { Çalıştığım kurumun politikaları amaçları ve uygulamaları arasında çok az ortak bir } \\
\text { yön vardır }\end{array}$ & 156 & 2,85 & 1,036 \\
\hline $\begin{array}{l}\text { Çalıştığım kurumda bir uygulamanın yapılacağı söyleniyorsa bunun gerçekleşip } \\
\text { gerçekleşmeyeceği konusunda kuşku duyarım }\end{array}$ & 156 & 2,86 & 1,104 \\
\hline $\begin{array}{l}\text { Çalıştığım kurumda çalışanlardan bir şey yapması beklenir ancak başka bir } \\
\text { davranışla ödüllendirilir }\end{array}$ & 156 & 2,89 & 1,057 \\
\hline $\begin{array}{l}\text { Çalıştığım kurumda yapılacağı söylenen şeyler ile gerçekleşenler arasında çok az } \\
\text { benzerlik görüyorum }\end{array}$ & 156 & 3,02 & 1,092 \\
\hline Bilişsel boyut toplam değeri & & 2,98 & 1,09 \\
\hline Çalıştığım kurumu düşündükçe sinirlenirim & 156 & 2,31 & 1,117 \\
\hline Çalıştı̆̆ım kurumu düşündükçe hiddetlenirim & 156 & 2,15 & ,998 \\
\hline Çalıştığım kurumu düşündükçe gerilim yaşarım & 156 & 2,26 & 1,040 \\
\hline Çalıştığım kurumu düşündükçe içimi bir endişe duygusu kaplar & 156 & 2,22 & 1,051 \\
\hline Duyuşsal boyut toplam değeri & & 2,23 & 1,05 \\
\hline Çalıştığım kurum dışındaki arkadaşlarıma iste olup bitenler konusunda yakınırım & 156 & 2,53 & 1,221 \\
\hline $\begin{array}{l}\text { Çalıştığım kurumdan ve çalışanlarından bahsedildiğinde birlikte çalıştığım kişilerle } \\
\text { anlamlı bir şekilde bakışırız }\end{array}$ & 156 & 2,96 & 1,272 \\
\hline Başkalarıyla çalıştığım kurumdaki islerin nasıl yürütüldüğü hakkında konuşurum & 156 & 3,00 & 1,260 \\
\hline Başkalarıyla çalıştığım kurumdaki uygulamaları ve politikaları eleştiririm & 156 & 2,81 & 1,192 \\
\hline Davranışsal boyut toplam değeri & & 2,82 & 1,24 \\
\hline Tüm Ölçek & & 2,70 & 1,11 \\
\hline
\end{tabular}

Tablo 3'te, katılımcıların "Çalıştığım kurumda söylenenler ile yapılanların farklı olduğuna inanıyorum" maddesine $(3,31)$ kararsızım, "Çalıştı̆̆ım kurumun politikaları amaçları ve uygulamaları arasında çok az ortak bir yön vardır" maddesine $(2,85)$ kararsızım, "Çalıştığım kurumda bir uygulamanın yapılacağı söyleniyorsa bunun gerçekleşip gerçekleşmeyeceği konusunda kuşku duyarım" maddesine $(2,86)$ kararsızım, "Çalıştığım kurumda çalışanlardan bir şey yapması beklenir ancak başka bir davranışla ödüllendirilir" maddesine $(2,86)$ kararsızım, "Çalıştığım kurumda yapılacağı söylenen şeyler ile gerçekleşenler arasında çok az benzerlik görüyorum" maddesine $(3,02)$ kararsızım, "Çalıştığım kurumu düşündükçe sinirlenirim" maddesine $(2,31)$ katılmıyorum, "Çalıştığım kurumu düşündükçe hiddetlenirim" maddesine $(2,15)$ katılmıyorum, "Çalıştı̆̆ım kurumu düşündükçe gerilim yaşarım" maddesine $(2,26)$ katılmıyorum, "Çalıştığım kurumu düşündükçe içimi bir endişe duygusu kaplar" maddesine $(2,22)$ katılmıyorum, "Çalıştığım kurum dışındaki arkadaşlarıma işte olup bitenler konusunda yakınırım" maddesine $(2,53)$ katılmıyorum, "Çalıştığım kurumdan ve çalışanlarından bahsedildiğinde birlikte çalıştığım kişilerle anlamlı bir şekilde bakışırız" maddesine $(2,96)$ kararsızım, "Başkalarıyla çalıştığım kurumdaki islerin nasıl yürütüldüğü hakkında konuşurum" maddesine $(3,00)$ kararsızım, "Başkalarıyla çalıştığım kurumdaki uygulamaları ve politikaları eleştiririm" maddesine $(2,81)$ kararsızım cevabı verdiği görülmektedir. Ölçeğe ait genel ortalama ise 2.70 'dir. Katılımcıların örgütsel sinizm düzeylerinin kararsızım etrafında toplandığı ve orta düzeye yakın olduğu söylenebilir. 
Bununla birlikte, genel sinizme verilen cevapların ortalamasına göre örgütsel sinizm daha düşük düzeyde çıkmıştır.

Ölçeğe faktör analizi uygulanmış ve analiz sonucunda Keiser-Meyer-Olkin testi sonucu 0,889 çıkmıştır ve bu değer verilerin faktör analizi için uygun olduğunu göstermektedir. Analiz sonucunda ölçekte yer alan maddelerin üç faktör altında toplandığı görülmüştür. Ölçekte yer alan beş madde bilişsel, dört madde duyuşsal ve dört madde davranışsal boyutu oluşturmaktadır. Bu değerlendirme de Brandes (1997) ve Dean (1998)'in örgütsel sinizm üzerine yaptıkları üç boyutlu değerlendirmeyle örtüşmektedir.

Örgütsel sinizmin boyutlarına ait ortalamalar ayrı ayrı incelendiğinde, bilişsel boyutun ortalaması $(2,98)$ kararsızım, duyuşsal boyutun ortalaması $(2,23)$ katılmıyorum, davranışsal boyutun ortalaması $(2,82)$ kararsızımdır. Katılımcıların cevapları incelendiğinde olaylar karşısında farkındalıklarının olduğu, duygularını zaman zaman davranışlara dönüştürdükleri ancak duygusal tepkiler vermedikleri söylenebilir.

\subsubsection{Genel Sinizm ve Örgütsel Sinizmin Boyutları Arasındaki İlişkinin Düzeyi}

Katılımcıların genel sinizm düzeylerinin, örgütsel sinizmin boyutları üzerinde ne derece etkili olduğunu anlamak üzere Pearson Korelasyon testi uygulanmıştır. Elde edilen sonuçlar Tablo 4 'te yer almaktadır.

Tablo 4. Genel Sinizm ve Örgütsel Sinizmin Boyutları Arasındaki Korelâsyon Sonuçları

\begin{tabular}{cccc}
\hline & Bilişsel Boyut & Duyuşsal Boyut & Davranışsal Boyut \\
\hline Genel Sinizm &, $451\left(^{* *}\right)$ &, $168\left(^{*}\right)$ &, $291\left(^{* *}\right)$ \\
\hline
\end{tabular}

Tablo 4'teki sonuçlar incelendiğinde, H1 hipotezinin desteklendiği görülmektedir. Genel sinizm ile örgütsel sinizmin boyutları arasında pozitif ve doğrusal bir ilişki vardır. Bireylerin genel sinizmi ve örgütsel sinizmin bilişsel boyutu arasındaki ilişki güçlü ve istatistiksel açıdan anlamlıdır. Genel sinizmin davranışsal boyut üzerindeki etkisi orta düzeyde, duyuşsal boyut üzerindeki etkisi düşük ama anlamlı düzeydedir.

\section{SONUÇ}

Genel sinizm ölçeği analiz sonuçları incelendiğinde, bireylerin diğer insanların çıkarları doğrultusunda hareket ettiklerini düşündükleri söylenebilir. Diğer insanların ahlak ilkelerine sadece görünürde uyduklarına, eylemlerinin ardında gizli niyetler olduğuna inanırlar. Bu nedenle de diğer insanlara güvenmezler. Yapılan araştırma sonucunda katılımcıların orta düzeyde genel sinik bireyler olduğu saptanmıştır. Örgütsel sinizm analiz sonuçları incelendiğinde ise bireylerin çalıştıkları kurumda vaat edilenlerin gerçekleşmediğini düşündükleri görülmektedir. Bu düşünce de bireyde örgüte karşı güvensizlik ve hayal kırıklığı gibi olumsuz duyguların ortaya çıkmasına yol açmaktadır. Bireyler örgütlerinin bütünlükten ve dürüstlükten yoksun olduğuna, yöneticilerinin tavır ve uygulamalarında güvenilmez olduklarına inanırlar. Bu durum da bireylerin örgütlerine karşı eleştirel bir tavır takınmalarına sebebiyet vermektedir. Genel sinizm ve örgütsel sinizm arasındaki ilişki incelendiğinde aralarında pozitif ve doğrusal bir ilişki olduğu saptanmıştır. Genel sinizm ve örgütsel sinizmin boyutları arasındaki ilişki incelendiğinde ise genel sinizmin etkisi en çok örgütsel sinizmin bilişsel boyutu üzerinde görülmektedir. Aralarındaki ilişki güçlü ve 
istatistiksel açıdan anlamlıdır. Genel sinizmin davranışsal boyut üzerindeki etkisinin orta düzeyde ve anlamlı, duyuşsal boyut üzerindeki etkisinin ise düşük seviyede ve anlamlı olduğu görülmektedir. Sinizm eğilimi gösteren bireylerin bu düşüncelerini duygusal boyutta kısmen daha az yaşadıkları ve duygusal boyuttan daha ziyade davranışsal boyuta dönüştürdükleri söylenebilir.

Bireylerde genel sinizm oluşmasında çeşitli sebepler etkili olmaktadır. Bireyin yetiştiği aile, etkileşim içinde bulunduğu çevresi, yer aldığı toplumun yapısı ve özellikleri etkileyici rol oynamaktadır. Genel sinizm eğilimi gösteren bireyler çoğunlukla bu durumlarını parçası oldukları örgütlerine de yansitmaktadırlar. Ancak bireylerdeki bu sinizmi ortadan kaldırabilmek adına bir takım örgütsel fonksiyonlar kullanılabilir. Örgütlerin gelecekteki başarısı, vizyonlarını gerçekleştirmeleri çalışanlarının verimi ile doğru orantılıdır. Çalışanlar kendilerini örgütlerine ne kadar bağlı hissederlerse o kadar başarı odaklı olacaklardır. Çalışanların güven ve sadakatini kazanmak ise yöneticilerin dürüst ve adil uygulamalarından geçmektedir. Çalışanlar örgütlerinin ahlak ilkeleri doğrultusunda hareket ettiklerini gördükleri takdirde, örgüte güven de besleyecektir. Çalışanlarda sinik tutumların oluşmasını engellemek adına örgütler vaatlerini gerçekleştirmeli, çalışanlarını hayal kırıklığına uğratmamalıdır. Hayal kırıklığı ve ihanete uğramış hissi bireyde birçok negatif duygu ve davranış oluşumunun tetiklenmesine sebebiyet verecektir. Yöneticiler çalışanlarına kendini değerli hissettirmelidir. Aksi takdirde çalışan örgütün başarısı için çaba göstermeyecektir. Çalışanların başarılı davranışlarına ödül veya takdir ile karşılık verilmesi bu davranışların sürekli olmasını sağlayacaktır. Davranışların meydana getirdiği sonuçlardan, o davranışa sebep olan birey sorumlu tutulmalıdır. Örgütün ücret politikasında adil olması çalışanlarda sömürülme hissi yaratmayacaktır. Unutulmamalıdır ki, sinizm bireyde örgüt politikaları sonucunda da ortaya çıkabilmektedir. Güven kazanma ve bireye değer verme birçok olumsuz durumun engellenmesinde kilit nokta olacaktır.

\section{KAYNAKÇA}

Abraham, R. (2000). Organizational Cynicism: Bases and Consequences. Generic, Social, and General Psychology Monographs , 126(3), 269-292.

Ajzen, I. (2001). Nature and Operation of Attitudes. Annual Review of Psychology, Vol: 52 , 2758.

Akman, G. (2013), Sağlık Çalışanlarının Örgütsel ve Genel Sinizm Düzeylerinin Karşılaştırılması, T.C. İstanbul Üniversitesi Sosyal Bilimler Enstitüsü, Yüksek Lisans Tezi, İstanbul.

Andersson, L. M., \& Bateman, T. S. (1997). Cynicism in the Workplace: Some Causes and Effects. Journal of Organizational Behavior, 18(5), 449-469.

Arslan, E. T. (2012). Süleyman Demirel Üniversitesi İktisadi ve İdari Bilimler Fakültesi Akademik Personelinin Genel ve Örgütsel Sinizm Düzeyi. Doğuş Üniversitesi Dergisi, 13(1), 12-27. 
Bies, R.J., \& Tripp, T. M. (1996). Beyond Distrust: “Getting Even and the Need for Revenge. Ed: Karmer, R. M. and Tyler, T. T, Trust in Organisations Frontiers of Theory and Research, Sage, London, pp. 246-260.

Brandes, P. M. (1997). Organizational Cynicism: Its Nature, Antecedents, and Consequences. Dissertation of Doctor of Philosophy, The University of Cincinnati, Cincinnati.

Dean, J. W., Brandes, P., \& Dharwadkar, R. (1998). Organizational Cynicism. The Academy of Management Review , 23(2), 341-352.

Demir, M., Ayas, S. ve Yıldız B. (2018). Örgütsel Sinizm ve İşe Yabancılaşma İlişkisi: Beş Yıldızlı Otel Çalışanları Üzerine Bir Araştırma, Yönetim Bilimleri Dergisi, 16(32), 231254.

Erdost, H. E., Karacaoğlu, K. ve Reyhanoğlu, M. (2007). Örgütsel Sinizm Kavramı ve İlgili Ölçeklerin Türkiye'deki Bir Firmada Test Edilmesi. 15. Ulusal Yönetim ve Organizasyon Kongresi Bildiri Kitabı (s. 514-524)., Sakarya Üniversitesi.

Izard, C. E. (1977). Human Emotions. New York: Plenum Press.

James, M. S. L. (2005). Antecedents and Consequences of Cynicism in Organizations: An Examination of the Potential Positive and Negative Effects on School Systems. Dissertation of Doctor of Philosophy, The Florida State University, Florida.

Kalağan, G. ve Güzeller, C. O. (2010). Öğretmenlerin Örgütsel Sinizm Düzeylerinin İncelenmesi. Pamukkale Üniversitesi Ĕ̆itim Fakültesi Dergisi, Sayı 27 , 83-97.

Mantere S., \& Martinsuo, M. (2001). Adopting and Questioning Strategy: Exploring The Roles of Cynicism And Dissent, European Group for Organisation Studies Colloquium (EGOS), July 5-7, Lyon, France. 1-5.

Özgener, Ş., Öğüt, A. ve Kaplan, M. (2008). İşgören-İşveren İlişkilerinde Yeni bir Paradigma: Örgütsel Sinizm, 53-72. (M. Özdevecioğlu, H. Kaplan, Dü, \& M. Görmen, Derleyici) İlke Yayınevi, Ankara.

Tokgöz N. ve Yılmaz, H. (2008). Örgütsel Sinisizm: Eskişehir Ve Alanya'daki Otel İşletmelerinde Bir Uygulama, Anadolu Üniversitesi Sosyal Bilimler Dergisi, 8(2), 283-305.

Weber, A. (1998 ). Felsefe Tarihi. 5. Baskı, Çev: H. V. Eralp, Sosyal Yayınlar, İstanbul.

Weiner, B. (1985). An Attributional Theory of Achievement Motivation and Emotion. Psychological Review, 92(4) ,548-573. 